\title{
The Representation of Social Actors in Mosques Shooting in New Zealand News Discourse: A Critical Discourse Analysis
}

\author{
Ralph Hery Budhiono \\ \{ralph.herybudhiono@kemdikbud.go.id\} \\ Balai Bahasa Kalimantan Tengah, Jalan Tingang Km 3,5, Palangka Raya, \\ Central Kalimantan, Indonesia
}

\begin{abstract}
A few weeks ago our world was shocked by the shooting of two mosques in the city of Christchurch, New Zealand. The worlds then condemned the action. Media all over the world blew the incident up in their reports, news, dan opinions. Some techniques to build such discourse concerning the given context are used to make point of views. This research will be focused on how these two online media, New Zealand Herald of New Zealand and detikcom of Indonesia, represent some social actors in their news discourse. The research aims to describe how some social actors are represented and their interpretation in the discourse based on van Leuween's. The discourses chosen will be two articles with the same and specific theme, the live streaming of the action. Texts to be analyzed are taken from those two media official sites. The research is mainly in the Critical Discourse Analysis and Functional Linguistics domain. Note-taking technique is used to compile data. The discourses are then broken down into smaller units. Social actors hereby are broken down into four categories: the shooter, the victims, the government, and the other parties. Based on the preliminary analysis, some factors are considered to decide which techniques are used to represents social actors involved, i.e. ideology and the background of the media. The government involved is relatively have the same representation, i.e. determination instead of indetermination. Meanwhile, in representing the main actor, the shooter, detikcom uses nomination technique by attaching a certain generic word, i.e. pelaku 'doer'. New Zealand Herald, at the same time, uses categorization by attaching a more accurate word, gunman.
\end{abstract}

Keywords: Critical Discourse Analysis, functional linguistics, news discourse, mass media, social actors representation, language ideology

\section{Introduction}

Several months ago, on March 15, 2019, at 13,40 local time, two mosques in Christchurch, New Zealand, were repeatedly fired by an unidentified man. The condition and situation before praying that day suddenly became people's worst nightmare. People were at their maximum panic. Victims, the people who were preparing themselves to pray, running around to save themselves. The world was shocked and curse the action. At least 50 victims dead and the other 20 are wounded seriously.

The world was extremely shocked for the action because it disfigures the city for its high tolerance and the city of peace and harmony. The city of Christchurch, and New Zealand in general, is relatively safe and secured from terrorism. It is never listed in the cities that are 
risky of high potency of terror and terrorism. To maintain the condition and to prevent the situation, the local government strongly recommends people to pray at home and not attending the mosque temporarily at that time.

The shooting of the two mosques should be the main attention for local and global media. Simultaneously, they cursed the action in many and various ways. The media then correlated the action with global terrorism.

How the media deliver the event to the readers will be the problem of this research paper. How social actors, people who involve and are involved in such a discourse or event, are represented and manifested in a news article will be discussed in the paper. The objective of the paper is to describe what techniques used by the writer of the article to represent social actors involved in a discourse. The problem and objective stated are based on the proposal stated by several scholars and quoted by Sobur [1]. He stated that media is not neutral. What comes inside, the news, is a mirror or representation of its ideology.

How certain social actors involved in the news of shooting are represented significantly different by these two media. The first one is an online media which is situated in Auckland, New Zealand Herald, and the second one is Indonesia-based online media, detikcom. The topics chosen are relatively equivalent, which will be how the shooter live-streamed his action. Those two articles are downloaded from those two media official site, www.detik.com and $w w w . n z h e r a l d . c o . n z$ respectively. Those two media are chosen for its representation of mainstream media genre, the online one.

Cited from Wikipedia (https://en.wikipedia.org/wiki/The_New_Zealand_Herald), the first media, New Zealand Herald (NZH), which is based and headquartered in Auckland, founded by William Crisholm Wilson and first issued on November 13, 1863. By March 2018, the print version of the media is now has 113.752 circulation, mainly in Auckland as its home base. It is known that NZH is a middle to high class-oriented media.

Meanwhile, detikcom is an Indonesian based media. It can be accessed comprehensively on July 9, 1998, by following the vast growth of internet access in Indonesia. It was born at the beginning of the period of press transparency which was restricted by the new order government before. The media is founded by four former journalists, Budiono Darsono, Yayan Sopyan, Abdul Rahman, and Didi Nugrahadi. In 2011 CT Corp took the ownership of the media. Now detikcom has more than three million hits a day (https://id.wikipedia.org/wiki/DetikCom).

There are at least two main considerations in choosing and deciding what media which will be the source of the research. The first one is how a certain local media deliver the news or the event that is happening in their area. The second one is, in searching for balance and equality, is how Indonesian media spread out the news that is happening outside its home base.

The background that drives the writer to choose the topic is that the media is not really neutral. The readers surely aware of this reality, but they never put it in mind. It never comes to their consideration in choosing what media to be read. This reality also drives the writer of the news articles in representing social actors involved. They have their techniques in doing so.

One of several experts who initiated critical discourse analysis, Theo van Leeuwen, stated that a middle to high class-oriented media tends to be on the side of the governments or the rulers, the elites [2]. The government perspectives are very dominant. That is, the government or the elites are always be specified and be nominated comprehensively. The elites come in their complete identity, including their name, position, and rank.

The middle to low class-oriented media is vice versa. They tend to be on the side of ordinary people, the grassroots. When ordinary people founded to be the victims, the identity 
of the victims are then to be covered. Meanwhile, the identity of the vicious governments and elites tend to be shown. What ideology underlies the media is visible through those two techniques.

Critical discourse analysis is grounded strongly on Habermas who claims that language is also a medium of domination and social force. For Halliday, a text is not considered to be a text per se. A text is the language that performing its social function [3]. In analyzing a text, context is attached to it, an inseparable item. Fairclough in advance stated that texts are social spaces in which two fundamental social processes simultaneously occur, cognition and representation of the world, and social interaction [4].

Brown and Yule in Mayr stated that discourse is simply a language in use and should be studied as such [5]. Talbot via Mayr also stated that text refers to the observable product of interaction, whereas discourse is the process of interaction itself, a cultural activity. It is also stated by Leech and Short in Mills that discourse is linguistic communication seen as a transaction between speaker and hearer, as an interpersonal activity whose form is determined by its social purpose [6].

The critical discourse analysis stands beyond the traditional understanding. It says that a text is not more than a piece of written language, it is meaningless, separated from its surroundings [7]. Based on those traditional views of the text, Fairclough and his colleagues proposed a study to correlate language, power, and ideology. Fairclough then stated that critical discourse analysis is an integration of text analysis, how it is produced, and analysis of the discursive events socioculturally [8].

News or news articles, based on van Leeuwen, need at least a set of participants with certain roles and role allocation. Those social actors allocate their role based on their interests. There are agents, victims, and beneficiaries. In advance, van Leeuwen said that the core of an event is a sequence of social action. Any simple events, someone meets coincidentally with his old friend, for instance, is a sequence of actions performed by some social actors. Later van Leeuwen said that there are several ways to represent social actors in a news article. What technique used by the writer depends on the importance of the information, the need to meet the media ideology, and the role of the governments and the other parties.

Some related researches have been conducted by several researchers. Aji has conducted a critical discourse analysis in 2017. He came with the study of the critical discourse analysis on Indonesian Republic Minister of Health controversial statement, which is a campaign of using condom for high-risk sex activities. He stated that it was a perspective difference that caused controversy. The Minister side came with pragmatics perspective, meanwhile the opposite side with their ideal perspective [9].

Wahyuni in 2016 conducted research entitled Government's Representation in "Rupiah Loyo, Harga Bensin Segera Naik" in Jawa Pos. She found that inclusion technique is found in representing Pertamina. The writer used the strategy of differentiation-indifferentiation and objectivation-abstraction [10].

Maemunah in 2011 conducted research which is entitled A Critical Discourse Analysis of Sentilan Sentilun in MetroTV. She concluded that there are nine actions found in that discourse. The ideology of the discourse, she continued, has no difference from the nation ideology [11].

Quite different from the other papers previously mentioned, this research paper will discuss a certain topic of how such social actors are represented in two relatively same topics. This research paper will also mention some techniques and strategies used by the writer in representing certain social actors. This is a descriptive research paper. The descriptive research means that the data to be analyzed are natural. Creswell stated that descriptive research tends 
to describe phenomena by that time. This is also a qualitative research paper since its analysis and discussion displayed qualitatively. A certain table is used to illustrate some data so it will be easily understood [12].

The sequence of the research is based on Sudaryanto's proposal. He stated that there are three main stages in conducting such research. Those are data collecting, analysis of the data, and presentation of the results [13]. The first stage, data collecting, consists of observation and note-taking stages. The writer, based on the objective of the research, observe and search some articles to meet the aim of the research. The writer then decided to choose two relatively same news article issued by those two media. This stage took place at the end of March 2019.

The second stage, data analysis, is started with breaking the data to be some smaller units, which are sentences. Based on these sentences, the writer then identified which words to be the social actors in every sentence, usually its subjects and frequently its objects.

To make the analysis much easier, social actors found are grouped into four categories, which are the doer, the victim, the government, and the other parties. Third step is to analyze and define which or what technique used by the news writer in representing those social actors. The last stage will be the presentation of the results. It includes such a discussion of what factors underlie the writer in representing such social actors.

\section{Result and Discussion}

The two articles to be analyzed in this research paper have relatively the same topic, which is the live-streamed of the action. Those two articles entitled "Penembak Masjid Selandia Baru Siarkan Aksinya via Livestreaming" and "Christchurch mosque shootings: Gunman livestreamed 17 minutes of shooting terror". Those two articles are then broken down into smaller units, which are sentences. Every sentence found then to be observed to identify and figure out what social actors used. Those two articles in line-specified form are displayed in the appendix. From this stage, the writer found some social actors to be displayed in table 1 and table 2 as follows.

Table 1. The representation of social actors in detikcom

\begin{tabular}{cll}
\hline Social actors & \multicolumn{1}{c}{ Representations } & Frequency \\
\hline The doer & Pelaku & 22 times \\
& Seorang kulit putih berusia 28 tahun & once \\
& Pria kulit putih berusia 30-40 tahun dan berseragam & once \\
& Dia & once \\
& Kita & once \\
& Empat orang terkait penembakan brutal & once \\
& Empat orang yang terdiri atas tiga wanita dan satu pria & once \\
& Warga negara Australia & once \\
The victim & Burung & once \\
& Wanita & once \\
The government & once \\
& Otoritas terkait & twice \\
& Otoritas setempat & once \\
& Komisioner Kepolisian setempat Mike Bush & once \\
& Dirinya & once \\
The other parties & Kepolisian Selandia Baru & once \\
& Penyedia layanan internet dan telekomunikasi & once \\
& Jurnalis TVNZ Anna Burns-Francis & once \\
\hline
\end{tabular}


By observing the table above, how the writer represents social actors involved can be clearly seen. The writer emphasizes his writing on the doer or the main actor of the event. However, no specific characters of the actors explained. The other parties have only once or twice appearance in the text.

Table 2. The representation of social actors in $N Z H$

\begin{tabular}{|c|c|c|}
\hline Social actors & Representations & Frequency \\
\hline \multirow[t]{12}{*}{ The doer } & Gunman & 5 times \\
\hline & Shooter & once \\
\hline & A white, 28-year-old Australian born man & once \\
\hline & Australian born citizen & once \\
\hline & Extremist, right-wing, violent terrorist & once \\
\hline & The man & twice \\
\hline & A polite, well-mannered young man & once \\
\hline & $\mathrm{He}$ & once \\
\hline & Two others & once \\
\hline & His (beige station wagon) & once \\
\hline & He (was perhaps radicalized) & once \\
\hline & $\begin{array}{l}\text { A man, } 28, \text { had been charged with murder and was due to appear } \\
\text { in Christchurch District Court }\end{array}$ & once \\
\hline The victim & - & \\
\hline \multirow{4}{*}{ The government } & Australian police & once \\
\hline & Australian Prime Minister Scott Morrison & once \\
\hline & $\mathrm{He}$ & once \\
\hline & NZ Police Commissioner Mike Bush & once \\
\hline \multirow[t]{9}{*}{ The other parties } & Former friends & once \\
\hline & Family members & once \\
\hline & Facebook Australia-New Zealand policy director Mia Garlick & once \\
\hline & Spark managing director Simon Moutter & \\
\hline & The company & once \\
\hline & Vodafone NZ spokesman Richard Llewellyn & once \\
\hline & Spark spokesman Andrew Pirrie & once \\
\hline & Australian media & once \\
\hline & & once \\
\hline
\end{tabular}

The second table above describes how the writer represents some social actors involver done by NZH. The writer emphasize his report on the doer, which is represented by the word gunman. Some specific features of the actors be written frequently.

Some techniques which are used by the writer in representing those social actors are discussed below.

\section{Exclusion dan Inclusion}

Based on van Leeuwen, exclusion is used when a certain social actor is not be included specifically in the article. This technique is used by NZH since they exclude some information deal with the victims or the number of it. No certain information about the victims or the number of them in $\mathrm{NZH}$, at least in the analyzed article. In detikcom, the technique of inclusion is used in informing or delivering information about the victims. It can be seen through the use of a certain phrase seorang wanita (article A, line no.16). This word is used in the sentence saat pelaku keluar dari masjid lagi, dia berulang kali menembaki seorang wanita di jalanan. 


\section{Activation}

This activation technique is used when social actors are represented based on what they do. They are treated as the doer of the action. This technique is one of several frequent techniques used in the news article. Its social actors can be seen from the word used. In this context, the words used are pelaku (article A line no.1, 2, 3, 4, 5, etc.), gunman (article B line no.1 and 4), and shooter (article B line no.16). The word pelaku is used for about 22 times in detikcom (55\%), meanwhile the words gunman and shooter are used for about $5(18 \%)$ and 2 times (6\%) respectively in NZH.

3. Genericization and Specification

This technique refers to how such social actors are stated, specifically or generally. As stated above, a middle to high class-oriented media tends to state the government and the rulers' side specifically. The other parties tend to be stated in general. The NZH and detikcom hereby can be stated as two middle to high class-oriented media. It is assumed because they can be accessed only by the favor of the internet.

The information or representation of the government side in those two articles are relatively the same. The government side is stated specifically, including its name and position. The other side, the victim, is stated in general, not specific enough in fact. No specific information about the victims. The genericization technique is shown by the phrase seorang kulit putih berusia 28 tahun (article A line no.3), Australian born citizen (article B line no.5), and former friends (article B line no.9).

The term specification refers to the use of words or other forms that consist of identities of the social actors. In detikcom, it is shown by the use of nominal phrase Komisioner Kepolisian setempat Mike Bush (article A line no.19) dan Jurnalis TVNZ Anna BurnsFrancis (article A line no.25). In NZH, it is shown by the use of these phrases: Australian Prime Minister Scott Morrison (article B line no.5), NZ Police Commissioner Mike Bush (article B line no.11), and Facebook Australia-New Zealand policy director Mia Garlick (article B line no.15). The identities of those social actors are stated clearly and specifically to make the public well informed.

4. Individualization dan Assimilation

Individualization refers to the technique that identifies such social actors individually, meanwhile assimilations refers to the technique that identifies such social actors categorize into a larger group. Individualization tend to be attached to the elites, while assimilation to the other parties in general.

The technique of individualization is relatively the same as specification. They inform and state some special identities of certain social actors. The uses of this technique are shown by these phrases: Facebook Australia-New Zealand policy director Mia Garlick (article B line no.15), Spark managing director Simon Moutter (article B line no.17), and Vodafone NZ spokesman Richard Llewellyn (article B line no.17).

On the other side, assimilation is also used in those two articles. They are shown by the use of the phrases pria kulit putih berusia 30-40 tahun dan berseragam (article A line no.26) and Australian born citizen (article B line no.5). These statements do not show any specific identities of social actors stated.

\section{Nomination dan Categorization}

There is a time when social actors are stated with their unique characters. It is called nomination. But there is also a time when social actors stated based on their roles and activities which is called categorization. A middle to high oriented media tend to nominate 
the elites. It is clearly shown by the phrases Komisioner Kepolisian setempat Mike Bush (article A line no.19) and Spark spokesman Andrew Pirrie (article B line no.18).

The categorization technique consists of two different strategies. Functionalization refers to the relation of such social actors with their activities or jobs, while identification refers to the statement of who exactly social actors are. Functionalization can be found in these phrases: extremist, right-wing, violent terrorist (article B line no.6) and a polite and well-mannered young man (article B line no.7). Identification can be found in these phrases: warga negara Australia (article A line no.25), former friends (article B line no.9), and Australian media (article B line no.19).

6. Personalization and Impersonalization

Personalization refers to the statement of social actors as natural human literally. It is represented by the use of personal pronouns or possessive pronouns. The use of personalization can be seen in the uses of these personal and possessive pronouns: dia and kita.

Impersonalization refers to the statement of social actors with some other aspects that have no direct relation with them as human. It consists of abstraction dan objectivation. Abstraction technique can be seen in was perhaps radicalized (article B line no. 9) dan $a$ man, 28, had been charged with murder and was due to appear in Christchurch District Court (article B line no. 11). Meanwhile, objectivation is shown by the use of the phrases Australian police (article B line no. 2) and Australian born (article B line no. 2).

Those two articles show some difference based on the analysis. The first table that consists of the representation of social actors derived from detikcom show a high intensity in stating and representing the doer. The word pelaku 'doer' is used for more than 20 times in the article. The other reference are also used. They are seorang kulit putih berusia 28 tahun dan pria kulit putih berusia 30-40 tahun dan berseragam. This is a quite big number especially when it is compared with the article in NZH. NZH uses the word gunman for 6 times and once for shooter.

In advance, NZH uses some alternatives way in stating the doer. They use some different expressions in representing the main actor. Phrases like extremist, right-wing, violent terrorist, a polite, well-mannered young man, and a man, 28, had been charged with murder and was due to appear in Christchurch District Court are used.

The victim or its identity is at least once explained. The word burung 'bird' is used in representing victims. This sentence is used by the shooter in his video: tampaknya kita tidak mendapatkan burungnya hari ini 'it seems we've got no birds today'. The sentence indicates that the shooter treat the victims inappropriately. It also indicates that the shooter intentionally did the shooting.

In NZH article, there is no such information or representation in relation to the victims. The number of the victims or their identities are excluded. It shows a certain bias with the media. The writer hereby consider some reasons why the media exclude the number or the identities of the victims. This is a way to drive public opinion. The public is conditioned to know the identity of the shooter, but not the victims. The aim of it, maybe, to maintain the condition peaceful.

Contradictively, detikcom has fewer explorations in representing social actors involved, especially in relation to shooter. Somehow they have such kind of lack of shooter identities. The words used by detikcom are somehow monotonous and have no variations. On the contrary, concerning the identity of the shooter, NZH has plenty of terms. The words and 
phrase like gunman, shooter, extremist, right-wing, violent terrorist, and so on are used frequently.

The government apparatus who comment concerning the event are stated and represented several times specifically. They use the phrase like otoritas terkait and Komisioner Kepolisian setempat Mike Bush. The other parties are represented in general at a glance.

The news showed in a media the next day is not news at all, news with no interest at all. The news is a composition of facts, the writer's opinion, and their ideology. Their opinion of course comes in a minimal dose for the sake of the substance of the news. One thing missed is the presence of ideology. It plays its roles within the news smoothly and undetectable.

\section{Conclusions}

Having analyzed the data, the writer concludes that the media is indeed not neutral at all. The news within would be such kind of aggregation or composition of many factors. Ideology and background of the media play an important role in gathering, producing, and delivering news to the public. It plays certain significant roles also in how the writer represents social actors involved. However, the main point in delivering news is the truth, substance, and accuracy of the news.

Media have to deliver what must be delivered, not only considering what can be delivered. This is important since news must be delivered as a whole, in one complete piece, nothing more nothing less. The techniques in how to represent the social actors are just a tool to identify and justify them accurately and appropriately. It should be done by not covering any facts that should be delivered to the public.

\section{References}

[1] Sobur, A. (2002). Analisis Teks Media. Bandung: Remaja Rosda Karya.

[2] van Leuween, T. (2008). Discourse and Practice. Oxford: Oxford University Press.

[3] Halliday, M. A. K., \& Hasan, R. (1992). Bahasa, Konteks, dan Teks; Aspek-aspek Bahasa dalam Pandangan Semiotik Sosial. Yogyakarta: UGM Press.

[4] Fairclough, N. (1995). Critical Discourse Analysis: The Critical Study of Language. New York: Longman.

[5] Mayr, A. et. al. (2012). Language and Power: An Introduction to Institutional Discourse. In A. et. al. Mayr (Ed.), Journal of English Linguistics. https://doi.org/10.1177/0075424212459055

[6] Mills, S. (1997). Discourse. London: Routledge.

[7] van Dijk, T. A. (2008). Discourse and Power. New York: Palgrave Macmillan.

[8] Wodak, R., \& Meyer, M. (Eds.). (2001). Methods of Critical Discourse Analysis. London: Sage Publications.

[9] Aji, E. N. W. (2012). Antara Pragmatisme Versus Idealisme: Analisis Wacana Kritis Kontroversi Pernyataan Menteri Kesehatan RI. Metalingua, 10(2), 151-159.

[10] Wahyuni, S. (2016). Representasi Pemerintah dalam Wacana "Rupiah Loyo, Harga Bensin Segera Naik” di Koran Jawa Pos. Sawerigading, 22(2), 281-290.

[11] Maemunah, E. (2011). Analisis Wacana Kritis terhadap Acara Sentilan Sentilun di Metro TV. Jalabahasa, 7(2), 21-32.

[12] Creswell, J. W. (2003). Research Design: Qualitative, Quantitative and Mixed Method Approach. California: Sage Publications. 
[13] Sudaryanto. (2015). Metode dan Aneka Teknik Analisis Bahasa. Yogyakarta: Sanata Darma University Press.

\section{Appendix}

Article A

1. Pelaku penembakan brutal di sebuah masjid di Christchurch, Selandia Baru sempat menayangkan aksi brutalnya via layanan live streaming di internet.

2. Video live streaming berdurasi 17 menit itu telah dihapus dari internet oleh otoritas terkait.

Seperti dilansir media lokal Selandia Baru, The New Zealand Herald, Jumat (15/3/2019), dalam live streaming itu, pelaku menyebut namanya sebagai Brenton Tarrant.

3. Nama itu mengarah pada seorang pria kulit putih berusia 28 tahun kelahiran Australia. Tayangan livestream itu dimulai dengan pelaku mengemudikan mobilnya ke Masjid Al Noor di Deans Ave, Christchurch.

4. Pelaku kemudian terlihat memarkirkan mobilnya di dekat jalan masuk ke masjid.

5. Mobil yang dikemudikan pelaku, sebut The New Zealand Herald, berisi sejumlah senjata api dan amunisi yang diletakkan di kursi penumpang bagian depan.

6. Adegan selanjutnya menunjukkan aksi brutal yang dilakukan pelaku.

7. Pelaku tampak mempersenjatai diri dan berjalan ke dalam masjid, dengan korban pertama ditembak di dekat pintu.

8. Dalam aksinya ini, pelaku menggunakan setidaknya satu pucuk senapan semi-otomatis dan banyak amunisi.

9. Tayangan kemudian menunjukkan pelaku melepas tembakan secara membabi-buta di dalam masjid.

10. Pelaku memeriksa setiap ruangan di dalam kompleks masjid itu dan berulang kali melepas tembakan.

11. Dia berhenti beberapa kali untuk mengisi ulang senjatanya.

12. Pelaku kemudian keluar dari masjid lewat pintu depan, setelah berada di dalam selamat tiga menit.

13. Di luar masjid, pelaku melepas tembakan secara acak ke arah mobil-mobil yang melintas. Setelah itu, pelaku kembali ke dalam mobilnya mereka Subaru untuk mengambil lebih banyak amunisi.

14. Pelaku lalu melepas tembakan ke arah jalanan tanpa target yang jelas.

15. Ke arah kamera, pelaku berkata: "Tampaknya kita tidak mendapatkan burungnya hari ini."

Selanjutnya, dia kembali masuk ke dalam masjid untuk memeriksa korban yang masih hidup dan melepas tembakan kembali.

16. Saat pelaku keluar dari masjid lagi, dia berulang kali menembaki seorang wanita di jalanan.

17. Pelaku kemudian masuk ke mobil dan meninggalkan lokasi.

18. Satu kendaraan yang nyaris mendekati mobilnya ditembaki beberapa kali dengan shotgun. Livestream itu berakhir setelah 17 menit dan adegan terakhir menunjukkan pelaku melajukan mobilnya dengan kecepatan tinggi.

19. Komisioner Kepolisian setempat, Mike Bush, menyatakan drinya menyadari keberadaan video livestreaming itu yang menyebar luas di media sosial.

20. Ditegaskan Bush, otoritas setempat berupaya menghapuskan video itu dari internet.

21. "Itu tidak seharusnya ada di domain publik,"sebutnya. Penyedia layanan internet dan telekomunikasi di Selandia Baru bersama-sama berupaya 
menghapus dan memblokir situs-situs yang menyebarluaskan video itu. Sejauh ini, Kepolisian Selandia Baru menahan empat orang terkait penembakan brutal di Christchurch.

22. Selain di Masjid Al Noor, serangan juga dilaporkan terjadi di sebuah masjid di pinggiran Linwood.

23. Empat orang yang terdiri atas tiga pria dan satu wanita itu ditahan terkait serangan di dua masjidtersebut.

Tidak diketahui pasti apakah pelaku yang menayangkan aksinya via layanan livestreaming ini termasuk dalam empat orang yang telah ditahan.

24. Identitas para pelaku penembakan brutal ini belum diungkap otoritas setempat.

25. Namun jurnalis TVNZ, Anna Burns-Francis, menuturkan kepada $C N N$ bahwa satu pelaku diyakini sebagai warga negara Australia.

26. Satu warga lokal bernama Robert Weatherhead menyebut pelaku sebagai pria 'kulit putih, berusia 30-40 tahun dan memakai seragam'.

27. Tak diketahui pasti seragam apa yang dipakainya.

Source:https://news.detik.com/internasional/d-4468693/penembak-masjid-selandia-baru siarkan-aksinya-via-livestreaming?_ga=2.208195796.751875298.1553480558-

813264791.1550735315

Article B

1. A horrific shooting at a Christchurch mosque was livestreamed for 17 minutes by the gunman.

2. Australian police have identified the shooter as Brenton Tarrant - a white, 28-year-old Australian-born man.

3. Twitter has shut down a user account in that name.

4. The gunman published an online link to a lengthy "manifesto", which the Herald has chosen not to report.

5. Australian Prime Minister Scott Morrison confirmed an individual taken into custody was an Australian-born citizen.

6. He called him "an extremist, right-wing, violent terrorist".

7. Sky News reported that the man's home town of Grafton was in shock, trying to come to terms with how a "polite, well-mannered young man" came to find himself on a path that led to Christchurch.

8. He was a student at the local high school and went on to work at a gym, where his former boss said he regularly volunteered his time to train kids for free.

9. In April 2010, Tarrant's father died suddenly of cancer aged 49, leading him to set off on a seven-year trip around the world. It was at some time during this journey that former friends now speculate he was "perhaps radicalised".

10. Family members who remained in the Grafton area were in shock and trying to come to terms with his acts, and were assisting police with their investigations, Sky News said.

11. NZ Police Commissioner Mike Bush said a man, 28, had been charged with murder and was due to appear in Christchurch District Court tomorrow morning.

12. "Two others remain in custody," Bush said late tonight.

13. Earlier today Bush said he was aware that footage of the shooting had appeared on social media and police were doing everything they could to get it removed.

14. "It shouldn't be in the public domain." 
15. Facebook Australia-New Zealand policy director Mia Garlick said videos which appeared to show the Christchurch shootings had been taken down.

16. "New Zealand Police alerted us to a video on Facebook shortly after the livestream commenced and we quickly removed both the shooter's Facebook and Instagram accounts and the video."

17. Spark managing director Simon Moutter said the company was working to close off websites attempting to distribute the footage.Vodafone NZ spokesman Richard Llewellyn said: "Industry players are working at a technical level now to block some of the hate sites involved in this content."

18. Spark spokesman Andrew Pirie said technical staff had identified three primary sites where footage had been posted but there were a number of "copycat" sites popping up. The internet providers had joined forces to block access to these sites, he said.

19. Australian media have reported that New South Wales counter-terrorism police were carrying out activities in the Coffs Harbour area of New South Wales.

20. It was not known whether "Tarrant" was from Coffs Harbour but he was certainly from NSW, Nine News Sydney reported.

21. It's believed the man may have family in Grafton, northeast of Coffs Harbour.

22. The 17-minute livestream began as the gunman drove to the Al Noor Mosque in Deans Ave.

23. His beige station wagon contains a cache of weapons and ammunition in the front passenger seat and boot, along with petrol canisters.

24. Filmed on a helmet camera it shows the gunman walking in to mosque front door and opening fire.

25. He is inside for three minutes, returns to his vehicle to get more ammunition and then reenters the mosque and opens fire again.

26. The 17-minute video ends as the gunman drives away at speed.

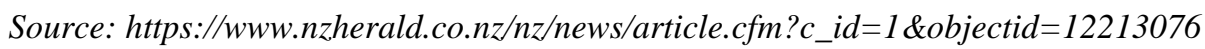

